\title{
METAANALYSIS OF RESEARCH STUDIES RELATED TO EFFECTS OF TELEVISED-VIOLENCE ON SOCIETY
}

\author{
Erum Hafeez ${ }^{*}$
}

\begin{abstract}
With the advent and popularity of Television by the end of 1950s and early 1960s, researchers focused the role and effects of this new medium on its growing audience. Himmelweit (1958) and Schramm (1961) are considered the pioneer researchers in the field. The volume of scientific studies regarding televised violence was largely increased following the landmark State Reports in US published between 1972 and 1982. These reports indicated that the proliferation of TV has exposed children to media violence at home. However, violence is rarely caused by a single factor, it rather involves multiple factors. Signorielli (2005) in her book Violence in the Media rightly commented that television plays a unique role of an entertaining storyteller but the increasing commercialization of TV is a serious matter of concern. ${ }^{l}$ The objective of this literature review is to provide a holistic overview of the landmark studies conducted on televised violence and its contribution to real life crimes and violence in society.
\end{abstract}

Keywords: Televised violence, juvenile delinquency, violent crime, literature review, landmark studies, imitation, mass society, limited effects, desensitization, mean-world syndrome

\section{Introduction}

Crime is defined "as a particular form of deviance that involves violation of laws reinforced by the political system. The nature of crime thus must be determined within the context of power and the political process." ${ }^{2}$

Criminal acts are broadly divided into violent offenses (against persons) and nonviolent offenses (against property). Violent Crimes which is also our area of interest in this research are taken seriously since they include offenses against people. It includes homicide (murder), aggravated assault, forcible rape, robbery, burglary, larceny-theft, auto-theft and arson which also come under the category of traditional or street crimes.

\footnotetext{
* Erum Hafeez, Ph.D. Assistant Professor, Media Studies, Institute of Business Management, Karachi ${ }^{1}$ Signorielli, N. "History Of Violence in the Media (TV); Contemporary World Issues." Violence in the Media- Contemporary World Issues Series. ABC-CLIO, Incorporated, 2005.

${ }^{2}$ Kerbo, Harold R. Sociology; Social Structure \& Social Conflict. California Polytechnic State University, (Islamabad: National Book Foundation, 2016).
} 


\section{Leading theories in the field}

Culture and Learning Theories draw attention to sub-cultural standards and their contribution in transmitting and teaching deviant behaviour e.g. effects of violence displayed on TV and movies. There is now some research evidence that TV violence can lead children to behave more violently. "Phillips (1982) suggests that children learn from onscreen violence that it is an acceptable and easy mean of achieving goals and expressing anger. But Coleman (1985) indicates that the relationship between the mass media and the deviant behaviour is quite complex." ${ }^{3}$

It is quite evident that the overt examples of media impact are horrifying but exceptional. Baran and Meyer (1974) said that there are very few people who really imitate onscreen violence and criminal acts compared to large majority of viewers who might relate or identify with their volatile icons that leaves a rather lasting model for them to follow. Millar and Dollard (1941) are of opinion that "People are likely to copy the onscreen behaviour that they watch; those behaviours would be reinforced and therefore learned as acceptable actions."

Social Learning through the use of media representations operates in one or all of three ways:

Observational Learning: The viewers of TV and Movies adopt new behavioural patterns by simply watching them onscreen. All of us discover how to use a gun, although majority of us have never seen it in real.

Inhibitory Effects: When viewers find a character is punished for adopting certain behaviour in the fictional world, they are less likely to imitate the act in real world since they are negatively reinforced.

Dis-inhibitory Effects assume that media images which demonstrate reward or positive reinforcement for any deviant act often motivate viewers towards such acts in real life. So while mere observation might result into learning the depicted acts, reel life associated reinforcement lead us to practice or discard them in real life.

Moreover, Aggressive Cues Research and development perspective tried adding quality precision to social learning theory. While active theory of television viewing suggested that viewers have more influence over their interactions with media than social learning theory seems to imply.

Primitive studies about the influence of TV and movies were predominated by the 'mass society paradigm' and their results were markedly different from the later researches which were representative of the 'limited effects paradigm'.

\footnotetext{
${ }^{3} \mathrm{Ibid}, 116$.

${ }^{4}$ Baran, Stanley J. Introduction to Mass Communication; Media Literacy and Culture. (Mayfield Publisher, 2011).
} 
Leonard Eron, Professor of Psychology at the University of Michigan's Institute for Social Research, conducted a longitudinal study in 1960. He studied third-graders in Columbia County in semi-rural New York. He observed that the more violent television these eight-year-olds watched at home, the more aggressive they were in school. Eron returned to Columbia County in 1971 when children from his sample were 19. He found that the boys who watched a lot of violent TV when they were eight were likely to get in trouble with the law when older. He returned to the place third time in 1982 when his subjects were thirty, to discover that the heavy televised violence viewers give more violent punishments to their children, convicted of more serious crimes, and often reported more aggressive by their spouses than others who watched less violent television. Speaking at a conference of the National Council for Families and Television, Eron concluded that around 10 percent of the violence in the USA can be credited to television. ${ }^{5}$

In mid to late 1960s, US experienced considerable turmoil, civil disobedience and urban unrest. During 1961, Senate Sub-Committee to investigate juvenile delinquency held yearlong hearings \& found that percentage of programs with violence had increased.

Eisenhower Commission was established in 1968 to examine the issues related to violence which sponsored George Gerbner's (1969) project to measure amount of violence in prime time and Weekend Day time network dramatic programs including films." 6

George Gerbner and Colleagues in 1967 at the University of Pennsylvania created a TV violence index and began counting acts of violence. He theorizes that "media violence leads to the mean world syndrome i.e. heavy doses of on screen violence and crime are daunting in the minds of heavy viewers and make them see their society as a scarier place than it really is. As a result these people become overly-concerned for their own safety and often willing to accept a police state for their security. Moreover, mediadepicted violence increases the tolerance of real life violence, known as the 'desensitizing effect', thus leads to more graphic violence. ${ }^{7}$

The decade of seventies witnessed widespread studies on the social implications of mass media. In 1971, Monroe Lefkowitz published "Television Violence and Child Aggression; A follow-up study which "certified that viewing heavy doses of violence and crime at the tender age of eight often leads to increasingly aggressive behaviour by the time they turn eighteen especially in boys. He controlled other potential factors, directly assessing media violence as an instigator of violent behaviour."

Michael Kunczik started his research around 1970 and printed in 1975 concluded that the "depiction of violence in the mass media can be dangerous for society although the majority of the viewers, including children and youth, will remain unaffected. But for an

\footnotetext{
${ }^{5}$ Stossel, S. The Man who counts the Killings. May 1997. www.theatlantic.com/issues/97may/gerbner.htm.

${ }^{6}$ Vivian, J, Allyn, and Bacon. Media of Mass Communication. 9th. Edited by Allyn and Bacon. 2009.

${ }^{7}$ ibid.

${ }^{8}$ Ibid., Stossel, S. The Man who counts the Killings. May

1997.www.theatlantic.com/issues/97may/gerbner.htm.
} 
inclined minority, negative effects are likely such as higher disposition to act violently and resolve conflicts by vicious means. He identified young males living in a volatile environment as the most endangered victims of the media violence." 9

Steven, Applefield \& Smith (1971), Drabman and Thomas (1974, 75 \& 76), Parke and Berkowits (1977) conducted several experiments in lab as well as in the field concluded that "television viewing is linked with the overt aggressive behaviour among the children." 10

Following the Eisenhower Commission report, within three years another extensive report was made public by the Surgeon General's Scientific Advisory Committee titled Television and Social Behaviour. The report establishes that the assumption that exposure to televised violence lead to aggressive behaviour in youth is applicable to only those segments of population who are already inclined to violence in real life.

Consecutively three leading television networks also launched studies in this field. CBS sponsored two projects:

i. a field experiment that proved no connection between exposure to televised violence and succeeding simulation of disruptive actions (Milgram \& Shotland, 1973) and

ii. a longitudinal research in Britain that found a link between watching excessive violence on television and involvement in destructive activities, such as killing and vandalism. (Belson, 1978)

Another TV channel ABC also commissioned multiple researches to psychiatrists who discovered that television simulated violence to only a tiny extent in children.NBC also launched an extensive panel study, but its findings were made public much later. Singer. (1981), Bryant Carveth \& Brown (1981), Atligikini (1983) also revealed a significant relationship between television violence viewing and actual aggressive behaviour. ${ }^{11}$

An updated version of the Surgeon General's Report (1972) was issued in 1982. It covered the issue from a wider perspective, included researches related to socialization, psychology, and perception of reality. The report resolved with consent of the research fraternity that "violence on television does lead to aggressive behaviour". ${ }^{12}$

\footnotetext{
${ }^{9}$ Kunczik, M. Recent Research on Media \& Violence; Media Violence \& Challenges facing Modern Societies. UNESCO, Asia Pacific Institute for Broadcasting Development; UNESCO, April 2003.

${ }^{10}$ Zuberi, Nisar A. "Effects of TV on Children of Middle Class Families in Karachi." 1992. http://prr.hec.gov.pk/Thesis/274 OR http://eprints.hec.gov.pk/624/.

${ }^{11}$ Zuberi, Nisar A. "Effects of TV on Children of Middle Class Families in Karachi." 1992. http://prr.hec.gov.pk/Thesis/274 OR http://eprints.hec.gov.pk/624/ .

${ }^{12}$ Department of Health and Human Services. "A Report of the Surgeon General: Youth Violence."

surgeongeneral.gov. January 2001. www. surgeongeneral. gov/library/youthviolence/chapter

4/appendix4b.html.
} 
Some researchers especially Wurtzel and Lometti (1984) and Bear (1984) highlighted that the study did not prove any causal connection, whereas majority including Chaffee (1984) and Murray (1984), agreed that the findings are reliable.

However, NBC panel study, published after more than a decade by Milavsky, Kessler, Stipp, \& Rubens, 1983, found a non-significant association between exposure to onscreen violence and real life violence and aggression.

Further, other researchers also re-examined NBC's data and indicated a minor connection between televised violence viewership and aggression among a population segment i.e. 'middle class girls'. ${ }^{13}$

In 1981 Brandon Centerwall, a professor of epidemiology at the University of Washington, hypothesized that television's impact can be derived from the South African experience where it was banned till 1975, under the Afrikaaner-dominated regime. The TV was then introduced to meet a dreadful situation where murder rates spiked within twelve years of its arrival. This observation is backed with the North American situation where murder rate sharply increased as a result of TV viewing in the start of $1955 .^{14}$

Singer and Rapaczynski (1984) after a longitudinal study which spanned over a period of 5 years ushered a result targeting pre-schoolers. Such children were most aggressive who watched the largest amount of TV at the age of nine. ${ }^{15}$

The debate kept engaging researchers and civil society for during all these years though it was somewhat subsided since the mid-eighties till 2001.

Williams (1986) conducted an elaborate field experiment in three Canadian communities. One town was about to receive television for the first time, another received Canadian TV, and the third received both Canadian and US Programs. Two years later, Williams and her colleagues learned that children in the town that had just received TV scored higher on measures of physical and verbal aggression as compared to children in the other two communities.

Same year, a series of panel studies were conducted by an international team of researchers (Huesmann, Lagerspetz and Eron, 1986). Data was gathered from young people in the United States, Finland, Australia, Israel, and Poland. Findings from the US and Polish studies reached a similar conclusion: Early TV viewing was related to later aggression. The Finish study found this relationship for boys and not girls. The Israeli study concluded that TV viewing seemed to be related to aggression for children living

${ }^{13}$ Wimmer, Roger D, and Joseph R Dominick. "Research in Media Effects." In Mass Media Research- An Introduction, by Roger D Wimmer and Joseph R Dominick, 393-396, chapter VII. Wadsworth Publishing, 2016.

${ }^{14}$ Ibid., Stossel, S. The Man who counts the Killings.

May1997.www.theatlantic.com/issues/97may/gerbner.htm.

${ }^{15}$ Ibid., Wimmer, Roger D, and Joseph R Dominick. "Research in Media Effects." In Mass Media ResearchAn Introduction, by Roger D Wimmer and Joseph R Dominick, 393-396, chapter VII. Wadsworth Publishing, 2016. 
in urban areas but not those for in rural areas. The Australian study failed to find a relationship. However, in most countries where a relationship between TV viewing and violence was found, it was proven relatively weak. Rosenthal (1986) said that even a fragile connection is likely to have considerable social effects, considering the realistic implications of this weak correlation.

Violent incidents at Columbian High School in Littleton, CO, and in other high schools at the end of the 20Th century ignited renewed interest in media violence among parents and policy makers. Media leaders were summoned before a congressional committee investigating this topic. ${ }^{16}$

Park and Comstock (1994) conducted the most comprehensive meta-analysis of media violence that investigated range of influences from 217 empirical researches published between 1957 and 1990, focused media violence and its possible correlation with the antisocial behaviour. The study concludes that "brief exposure to violent dramatic presentations in TV or films causes short-term increases in the aggressive behaviour of youth including physical aggression." 17

However, not all youth seems to be affected equally by media violence. There is a disparity where effects are most prominent. It is noted that "the already provoked youngsters, with pre-disposition to being aggressive, are the most common targets.'(Berkowitz, 1933; Bushman, 1995; Geen \& O’Neal, 1969; Anderson \& Dill, 2000; Bushman, 1995; Bushman \& Geen, 1990; Frederick \& Stein, 1973; Josephson, $1987)^{18}$

Wilbur Schramm said "TV may be harmful to some children, but for most children, it is neither harmful, nor beneficial." ${ }^{19}$

The last report of the 3-year National TV Violence Study in America found that TV violence posed a serious threat to children. It encourages children to learn aggressive behaviour. Furthermore, it discovered that "the proportion of prime time broadcast and basic cable shows with violence has been increased since 1994 and "violence is often glamourized and sanitized, initiated by good characters and role models (comprising of around $40 \%$ acts), thereby "teaching children that violence is desirable, necessary and painless." ${ }^{20}$

Social Science studies carried out over half a century concurs that exposure to sadistic TV content has negative implications especially for children and youth. Findings of

\footnotetext{
${ }^{16}$ Department of Health and Human Services. "A Report of the Surgeon General: Youth Violence." surgeongeneral.gov. January 2001. www. surgeongeneral. gov/library/youthviolence/chapter 4/appendix4b.html.

${ }^{17}$ National TV Violence Study, 1996-1997." Mediaawareness.ca .

www.mediaawareness.ca/eng/resources/research_documents/rep/violence.

${ }^{18}$ Ibid. National TV Violence Study, 1996-1997

${ }^{19}$ Wilbur S, Jack L, and Edward B. Parker, Television in the Lives of Our Children-(Stanford, CA: Stanford University Press, 1961): 1-169.

${ }^{20}$ Aidman, A. “Television Violence; Content, Context, and Consequences.” Eric Digest.com. 1997. http://www.ericdigests.org/1998-2/television.htm.
} 
most studies highlight three possible ways in which violent TV programs can influence vulnerable viewers:

i. Media Violence can promote and teach children aggressive actions and mannerism

ii. It can develop anxious and negative attitudes about the real world.

iii. It can make viewers less sensitive to the reality and glamorize violence

According to Eron (1992), Television is the deep rooted cause of violence, crime and aggression in society. This statement has been backed by the lab and life studies and proves that on screen violence affects all ages, genders, socio-economic and intelligence levels. $^{21}$

The characters on screen are powerful sources that elicit the attractiveness to glue children and adolescents to the TV. This can be problematic as viewers identify themselves with such character and consider them idols. Both fictitious as well as realistic violence are considered high risk especially when it is projected that violence is justified in certain situation, has minimal consequences and should be acknowledged when it protects weak against social injustice.

A content analysis of fictional programs broadcast on Canada's eight largest television networks has indicated that the level of violence on Canadian television, although overall not as high as American Television's violence content, reached comparable levels on occasion, particularly on the private networks. A survey conducted on a sample of university students provides evidence that television viewing affects not only explicit behaviours, but also beliefs concerning the level of violence in one's surroundings. Even in a population of media-literate adults, although their level of fear does not seem to be influenced in the same way. ${ }^{22}$

In Pakistan, one major study on effects of television programmes and commercial spot messages on Children was conducted in 1978 by Dr Alay Ahmad who belonged to the Department of Psychology, University of Peshawar. His study explored TV programme preference and its causes, viewing hours, learning form TV programmes and advertisements, nature of communication with the family members while watching \& preference between movies and TV Programmes. The study was conducted with a sample of 144 children living in Peshawar University Campus and thus was limited in scope. $^{23}$

\footnotetext{
${ }^{21}$ L. Rowell Huesmann, Jessica Moise-Titus, Cheryl-Lynn Podolski, and Leonard D. Eron. "Longitudinal Relations Between Children's Exposure to TV Violence and.” Developmental Psychology (American Psychological Association, Inc) 39, no. 2 (2003): 201-221.

${ }^{22}$ Gosselin, A, and J DeGuise. "Violence on Canadian Television \& some of its Cognitive Effects." Canadian Journal of Communication 22, no. 2 (1997).

${ }^{23}$ Ibid., Zuberi, Nisar A. "Effects of TV on Children of Middle Class Families in Karachi." 1992.

http://prr.hec.gov.pk/Thesis/274 OR http://eprints.hec.gov.pk/624/.
} 
Violence in the Dramatized Entertainment of PTV; A Profile by Fazal Rahim Khan \& Ibadullah Rashid was another study completed in 1989. The study was a part of a large project involving eight Asian countries in order to generate comparative data on violence in Asian countries. The study indicates a prevalence of violence in the fictional world of PTV. This prevalence virtually remains undiminished when the definition of violence is narrowed down by excluding the violent incidents of purely verbal type. Violence on PTV was more pronounced and pervasive (15.4\%) when compared with the amount of violence on the US television (1.7\%). Although a higher percent of the prime time programme were violent, violence was more frequent, concentrated and more wide-ranging (in terms of participants) on the non-primetime fare on PTV." 24

Nisar Zuberi conducted a research study completed in July 1991 on Effects of TV on Children of Middle Class Families in Karachi. It was a cross sectional survey study that also explored the effects of TV violence on young viewers alongside other effects.

According to the findings, "heavy television viewer children of Karachi are more aggressive as they are fond of using fire arms and find pride in doing so. They are taught to fight the enemy and anyone coming in their way should be dealt with unemotionally. Action packed movies and TV programs are sought after by most children and parents wouldn't mind sitting beside them and watching it together." 25

Observational Learning is the major psychological process underlying effects of media violence on aggressive behaviour. (Department of Health and Human Services 2001) A substantial number of laboratory and field experiments over the past half century have examined whether children exposed to violence in films or on TV behave more aggressively immediately afterwards.

In 2001, the Surgeon General issued a report entitled Youth Violence, a document that included a study of the factors that contributed most to antisocial behaviour among young people. The report ascertained the "media violence was a linchpin of the aggression. Other high risk factors include family influences, peer group attitudes, socio economic status and substance abuse which in most cases play more influential role than media." ${ }^{26}$ (Department of Health and Human Services 2001)

Despite this renewed interest, the number of research studies examining media violence has decreased in the last few years. Communications abstracts lists a total of only 3 audience studies in 2010 s that addressed this topic. ${ }^{27}$

\footnotetext{
${ }^{24}$ Khan, Rahim,F, and I Rashid. "Violence in the Dramatized Entertainment of PTV." Research Journal Gomal University (B)13, no. 2 (1993): 205-222.

${ }^{25}$ Ibid., Zuberi

${ }^{26}$ Ibid., Department of Health and Human Services. "A Report of the Surgeon General: Youth Violence." surgeongeneral.gov. January 2001. www. surgeongeneral. gov/library/youthviolence/chapter 4

${ }^{27}$ Ibid., Wimmer, Roger D, and Joseph R Dominick. "Research in Media Effects." In Mass Media ResearchAn Introduction, by Roger D Wimmer and Joseph R Dominick, 393-396, chapter VII. Wadsworth Publishing, 2016.
} 


\section{Studies that defer the hypothesis}

Around 200 to 300 lab experiments, field studies and correlation studies have been done on media violence and their results are dubious and inconsistent. ${ }^{28}$

The belief of the majority neglects the opposing hypothesis known as Catharsis which holds that viewing television leads to a reduction in aggressive behaviour because watching violence may often become a source of releasing the tension for aggression.

Fesback and Singer had shown that in no instance did viewing aggressive TV lead to an increase in aggression and that for boys who are initially high in aggressive behaviour and low in fantasy aggression, watching TV shows was related to reduced aggression but their finding has not been confirmed by other latter studies. ${ }^{29}$ (Zuberi 1992)

Jib Fowles and others' experiments have found more aggressive behaviour after viewing non-violent shows like Sesame Street. ${ }^{30}$ (Fowles 1999)

Professor Jonathan Freedman, "who reviewed media violence literature in 1980 concluded that research didn't prove either strong or consistent support for the hypothesis that exposure to media violence causes aggression or crime. Updating his research in 2002, he reported that fewer than half the studies support a casual effect." ${ }^{31}$ (Freedman 2008)

Some Correlation researches indicate a connection between the subject's extent of violent content exposure and subsequent hostile behaviour; however, it doesn't establish causation. A combination of factors which include education level, social back ground, attitudes, genetic predisposition and economic status add to the reasons for entertainment preferences of watching TV or cinema and the after effects of behavior. ${ }^{32}$ (Federal Trade Commission September 2000 printed in July 2001)

There have been cases where offenders and deviants claim to have imitated certain scenes of a violent movie or TV show. But it is also a reality that millions of others never incline to such imitation suggest that predisposition is the important factor in most such cases(Douglas and Olshaker 1999). ${ }^{33}$

In this regard, media literacy is an alternative approach to censorship which suggests that the best ways to address concerns about all sorts of negative media messages are

\footnotetext{
${ }^{28}$ FEPP. Fact Sheets ; Media Violence. 2016. http://www.fepproject.org/factsheets/mediaviolence.html (accessed June 2016).

${ }^{29}$ Ibid., Zuberi, Nisar A. "Effects of TV on Children of Middle Class Families in Karachi." 1992.

http://prr.hec.gov.pk/Thesis/274 OR http://eprints.hec.gov.pk/624/ .

${ }^{30}$ Fowles, J. Jib Fowles \& Others; the Case for TV Violence. Sage Publications, 1999.

${ }^{31}$ Freedman, J. "Media Violence \& its Effects on Aggression; Assessing the Scientific Evidence." University of Toronto, University of Toronto, 2008.

${ }^{32}$ Federal Trade Commission. Marketing Violent Entertainment to Children, A review of Self-Regulation and Independent Practices in Motion Pictures. Washington D.C.: Federal Trade Commission, Sept. 2000 printed in July 2001.

${ }^{33}$ Douglas, J, and M Olshaker. “The Anatomy of Motive.” 82-87. New York: Scribner, 1999.
} 
media education and increasing demand for creative, constructive and non-violent TV programme. $^{34}$

\section{Summary of research studies on television violence}

The critical review of the available literature on the topic reveals the fact that the most effective and extensive researches were conducted on the impact of violence in television programs than that of motion pictures. Literature review of television related studies disclosed that TV is widely criticized as one of the key factors to real-life violence mainly because children are directly exposed to media violence at home and television often serves as the primary storyteller in the early age, controlled by the multinationals and media giants with commercial motives.

Several researches indicated that the depiction of violence in media affects various segments of society differently. While majority of the recipients remain unaffected, it might encourage young males living in a volatile environment to act aggressively and use vicious means to resolve conflicts.

Overall Social researches conducted over the past eighty years on media violence supported that violent content on television has negatives consequences on vulnerable sections of society such as children (Cooper, 1996), youth (Park \& Comestock, 1994) especially aggressive and aroused youths (Berkowitz, 1933; , Green \& O' Neal, 1969; Frederick, 1973, Josephson, 1987; Bushman, 1995; Anderson \& Dill, 2000)

Media violence and crime not only provoked prone viewers but it also affected other social segments in a subtle and different manner by cultivating fearful attitudes about the real world or simply desensitizing them to real world agony through excessive exposure to fictional violence

There are very few studies such as that of Feshback and Singer (1971), which supported Aristotle's catharsis theory holds that viewing onscreen violence, leads to reduction in aggression as it provides an outlet for pent up emotions and tensions

Professor Jonathan's thorough analysis of the research literature (1980) available on the topic leads us to the conclusion that "overall scientific studies are unable to provide strong and reliable evidence for the assumption that exposure to media violence cause aggression or crime. According to his updated review in 2016, "fewer than half the studies support a causal effect".

However, researchers justifiably claimed that even a weak link between real and media violence could have significant consequences considering the possible magnitude of its implications.

${ }^{34}$ Heins, M, and C Cho. "Media Literacy:An Alternative to Censorship." Free Expression Policy Project. 2013.

${ }^{35}$ Ibid., Freedman 


\section{Bibliography}

Aidman, A. "Television Violence; Content, Context, and Consequences." Eric Digest.com. 1997. http://www.ericdigests.org/1998-2/television.htm.

Baran, Stanley J. Introduction to Mass Communication; Media Literacy and Culture. Mayfield Publisher, 2011.

Department of Health and Human Services. "A Report of the Surgeon General: Youth Violence.” surgeongeneral.gov. January 2001. www. surgeongeneral. gov/library/youthviolence/chapter 4/appendix4b.html.

Douglas, J, and M Olshaker. "The Anatomy of Motive." 82-87. New York: Scribner, 1999.

Federal Trade Commission. Marketing Violent Entertainment to Children, A review of Self-Regulation and Independent Practices in Motion Pictures. Washington D.C.: Federal Trade Commission, Sept. 2000 printed in July 2001.

FEPP. Fact Sheets ; Media Violence. 2016.

http://www.fepproject.org/factsheets/mediaviolence.html (accessed Jan 2016).

Fowles, J. Jib Fowles \& Others; the Case for TV Violence. Sage Publications, 1999.

Freedman, J. "Media Violence \& its Effects on Aggression; Assessing the Scientific Evidence." University of Toronto, University of Toronto, 2008.

Gosselin, A, and J DeGuise. "Violence on Canadian Television \& some of its Cognitive Effects." Canadian Journal of Communication 22, no. 2 (1997).

Heins, M, and C Cho. "Media Literacy:An Alternative to Censorship." Free Expression Policy Project. 2013.

Kerbo, Harold R. Sociology; Social Structure \& Social Conflict. California Polytechnic State University: National Book Foundation, Islamabad, 2016.

Khan, Rahim,F, and I Rashid. "Violence in the Dramatized Entertainment of PTV." Research Journal Gomal University (B)13, no. 2 (1993): 205-222.

Kunczik, M. Recent Research on Media \& Violence; Media Violence \& Challenges facing Modern Societies. UNESCO, Asia Pacific Institute for Broadcasting Development; UNESCO, April 2003.

L. Rowell Huesmann, Jessica Moise-Titus, Cheryl-Lynn Podolski, and Leonard D. Eron. "Longitudinal Relations Between Children's Exposure to TV Violence and."

Developmental Psychology (American Psychological Association, Inc) 39, no. 2 (2003): 201-221. 
“National TV Violence Study, 1996-1997." Mediaawareness.ca . www.mediaawareness.ca/eng/resources/research_documents/rep/violence.

Signorielli, N. "History Of Violence in the Media (TV); Contemporary World Issues." In Violence in the Media- Contemporary World Issues Series. ABC-CLIO, Incorporated, 2005.

Stossel, S. The Man who counts the Killings. May 1997.

www.theatlantic.com/issues/97may/gerbner.htm.

Vivian, J, Allyn, and Bacon. Media of Mass Communication. 9th. Edited by Allyn and Bacon. 2009.

Wimmer, Roger D, and Joseph R Dominick. "Research in Media Effects." In Mass Media Research- An Introduction, by Roger D Wimmer and Joseph R Dominick, 393396, chapter VII. Wadsworth Publishing, 2016.

Wilbur S, Jack L, and Edward B. Parker, Television in the Lives of Our ChildrenStanford, CA: Stanford University Press, (1961): 1-169.

Zuberi, Nisar A. "Effects of TV on Children of Middle Class Families in Karachi." 1992. http://prr.hec.gov.pk/Thesis/274 OR http://eprints.hec.gov.pk/624/. 